\title{
Devisa dan Turis Mancanegara
}

\author{
Teguh Permana ${ }^{\mathrm{a}, 1, *}$, Andriani Puspitaningsih ${ }^{\mathrm{b}, 2}$ \\ ${ }^{a}$ IESP FEB UHO, Kota Kendari 93231, Indonesia \\ ${ }^{b}$ IESP FEB UHO, Kota Kendari 93231, Indonesia \\ ${ }^{1}$ teguhpermana@gmail.com*; 2 andrianipuspitaningsih@gmail.com \\ * corresponding author
}

ARTICLE INFO

Article history:

Submitted: May 23, 2020

Reviewed: June 10, 2020

Accepted: June 19, 2020

Published: June 30, 2020

Keywords: foreign exchange, tourist, covid-19

\section{ABSTRACT}

This study aims to determine the economic conditions in terms of foreign tourists as foreign exchange earners during the Covid19 pandemic in Indonesia. The research method used is descriptive method and content analysis. Broadly speaking, the systematic writing is more narrative that collects the opinions of experts, journals, books and writings published on the internet related to foreign exchange and foreign tourists. The results showed that foreign exchange and foreign tourists experienced a very large decline since the spread of the Covid19 virus. The research findings imply that the government must immediately take quick steps to overcome this in order to increase the country's foreign exchange.

Kata kunci: devisa, turis, covid19.

\begin{abstract}
ABSTRAK
Penelitian ini bertujuan untuk mengetahui kondisi ekonomi dari sisi turis mancanegara sebagai penghasil devisa negara dalam masa pandemi Covid19 di Indonesia. Metode penelitian yang dilakukan adalah metode deskriptif dan analisis isi. Secara garis besar, sistematika penulisan ini lebih bersifat narasi yang mengumpulkan pendapat para ahli, jurnal, buku serta tulisan yang dimuat di internet terkait dengan devisa dan turis mancanegara. Hasil penelitian menunjukkan bahwa devisa dan turis mancanegara mengalami penurunan yang sangat besar sejak menyebarnya virus Covid19. Temuan penelitian mengimplikasikan bahwa pemerintah harus segera mengambil langkah-langkah yang cepat untuk mengatasi hal ini guna kembali meningkatkan devisa negara.
\end{abstract}

Copyright (c) 2020 Politeknik Negeri Samarinda. All rights reserved.

\section{Pendahuluan}

Pembangunan ekonomi terus dilakukan oleh pemerintah dalam berbagai hal terutama infrastruktur pada masa pemerintahan sekarang ini. Tidak hanya infrastruktur tetapi pemerintah juga melakukan upaya pengembangan dalam bidang pariwisata. Hal itu terlihat dengan dikeluarkannya kebijakan insentif pajak dan diskon tiket pesawat.

Berdasarkan data Kementerian Pariwisata pendapatan devisa dari sektor pariwisata pada 2015 mencapai US\$ 12,23 miliar atau setara Rp 169 triliun. Jumlah tersebut berada di urutan ke empat sebagai penyumbang devisa terbesar pada 2015, di bawah migas, batu bara dan kelapa sawit. Kemudian pada 2019, pendapatan devisa dari pariwisata ditargetkan sebesar US\$ 20 miliar dan menjadi yang terbesar mengalahkan hasil ekspor sawit maupun migas. Untuk mencapai target tersebut, pemerintah menargetkan 20 juta kunjungan wisman pada 2019 (databoks.katadata.co.id, 2018) 
Menteri Pariwisata dan Ekonomi Kreatif Wishnutama mengatakan devisa yang berasal dari sector pariwisata semula diprediksi mencapai USD20 miliar, namun karena pandemi ini diperkirakan hanya separuhnya saja (Economy.okezone.com, 2020).

Berdasarkan data dari Kemenparekraf bahwa setiap tahun terjadi peningkatan jumlah devisa dari sektor pariwisata. Pada tahun 2009 penerimaan devisa dari sektor pariwisata sebesar 6,3 Miliar USDolar dan pada tahun 2019 sebesar 17,6 Miliar USDolar.

Cadangan devisa yang mengalami penurunan secara terus menerus dapat mengganggu perekonomian suatu negara, langkanya cadangan devisa menyebabkan tidak memungkinkannya mengimpor barangbarang modal dalam rangka pembangunan ekonomi. Sumber keuangan dari luar dapat memainkan peranan penting dalam usaha melengkapi kekurangan sumber daya berupa devisa, sehingga dengan adanya aliran modal dari luar akan mempengaruhi cadangan devisa suatu negara.

Sayoga dan Tan (2017) menemukan bahwa utang luar negeri, nilai ekspor dan kurs berpengaruh terhadap cadangan devisa di Indonesia. Sedangkan Febriyenti, Aimon dan Azhar (2013) menemukan bahwa net ekspor, utang luar negeri dan cadangan devisa sebelumnya berpengaruh terhadap cadangan devisa di Indonesia. Dari dua penelitian diatas belum melihat dari sisi pariwisata khususnya turis mancanegara.

Akhtar, Sadekin dan Saha (2014) menemukan hasil penelitian bahwa semakin banyak turis yang datang maka semakin banyak pula pendapatan dari devisa yang di dapatkan dan hal itu dapat memulihkan perekonomian Bangladesh.

Penelitian ini menggunakan analisis isi atau content analysis untuk melihat secara mendalam hubungan devisa dan turis mancanegara. Diharapkan penelitian ini bisa memberi sumbangan pemikiran untuk kemajuan pariwisata di Indonesia khususnya peningkatan jumlah turis mancanegara.

\section{Review Tinjauan Pustaka}

Cadangan devisa merupakan bagian dari tabungan nasional sehingga pertumbuhan dan besar kecilnya cadangan devisa merupakan sinyal bagi global financial markets mengenai kredibilitas kebijakan moneter dan creditworthiness suatu negara (Gandhi,2006).

Berdasarkan konsep international reserves and foreign currency liquidity (IRFCL) yang dikeluarkan oleh IMF, cadangan devisa didefinisikan sebagai seluruh aktiva luar negeri yang dikuasai oleh otoritas moneter dan dapat digunakan setiap waktu guna membiayai ketidakseimbangan neraca pembayaran atau dalam rangka stabilitas moneter dengan melakukan intervensi di pasar valuta asing dan untuk tujuan lainnya. Dari definisi ini dapat dilihat adanya dua fungsi penting cadangan devisa, yaitu untuk membiayai ketidakseimbangan neraca pembayaran dan untuk menjaga stabilitas moneter. Dalam kaitan dengan neraca pembayaran, cadangan devisa biasanya digunakan untuk membiayai impor dan membayar kewajiban luar negeri, sementara dalam fungsinya untuk menjaga stabilitas moneter adalah untuk mempertahankan nilai tukar mata uang (Gandhi, 2006).

Motif kepemilikan cadangan devisa dapat dianalogikan dengan motif seseorang atau individu untuk memegang uang (Roger,1993). Seperti diketahui ada tiga motif mengapa seseorang ingin memegang uang, yaitu motif transaksi, motif berjagajaga, dan motif spekulasi. Dalam hal cadangan devisa, motif transaksi ditujukan terutama untuk mencukupi kebutuhan likuiditas internasional, membiayai defisit neraca pembayaran, dan memberikan jaminan kepada pihak eksternal (para kreditor dan rating agency) bahwa kewajiban luar negeri senantiasa dapat dibayar tepat waktu (zero default) dengan biaya seminimal mungkin tanpa mengurangi optimalisasi pendapatan bagi negara. Motif berjaga-jaga ditujukan terutama dalam rangka pelaksanaan kebijakan moneter dan kebijakan nilai tukar, yaitu memelihara kepercayaan pasar, melakukan intervensi pasar sebagai upaya mengendalikan volatilitas nilai tukar apabila diperlukan, meredam market shocks bila terjadi krisis6, dan memberikan kepercayaan kepada pelaku pasar domestik bahwa mata uang domestik senantiasa di-back up oleh aset valas. Motif spekulasi ditujukan terutama untuk memperoleh return dari 
kegiatan investasi cadangan devisa (Gandhi, 2006).

\section{Metodologi Penelitian}

Metode penelitian yang dilakukan adalah metode deskriptif dan analisis isi atau analisis konten. Secara garis besar, sistematika penulisan ini lebih bersifat narasi yang mengumpulkan pendapat para ahli, jurnal, buku serta tulisan yang dimuat di internet terkait dengan devisa dan turis mancanegara

\section{Hasil dan Diskusi}

Pariwisata selalu menarik untuk dibicarakan dan tidak pernah ada matinya. Setiap manusia pasti butuh istirahat dan rehat sejenak dari padatnya waktu bekerja. Di sinilah pariwisata memegang peran penting untuk memberi relaksasi dengan rekreasi ke tempat-tempat wisata.

Dari hasil telaah penulis bahwa terjadi penurunan jumlah turis sejak virus corona menyebar di Dunia. Januari 2020 jumlah turis mancanegara berjumlah 1,27 juta jiwa. Dan pada bulan Februari 2020 turun menjadi 863.960 jiwa. Kemudian pada bulan maret kembali turun menjadi 470.898 jiwa. Dan pada bulan April kembali menurun sebesar 160.042 jiwa.

Dari data diatas terlihat bahwa terjadi terus penurunan jumlah wisman yang menjadi sumber penerimaan devisa negara. Walaupun sebenarnya perlu di cek kembali mengapa pada bulan April masih ada jumlah wisman padahal harusnya kedatangan luar negeri sudah harus dihentikan dalam rangka mencegah semakin menyebarnya virus corona/covid19.

Jika kita bandingkan dengan hasil penelitian Aktar dkk yang menyatakan bahwa sektor pariwisata sangat membantu memulihkan perekonomian Bangladesh. Hal ini juga akan berlaku di Indonesia di tengah pandemi ini. Dengan lamanya masyarakat dianjurkan oleh pemerintah untuk bekerja dari rumah dan belajar dari rumah sampai muncul aturan PSBB (pembatasan social berskala besar) maka masyarakat akan butuh rekreasi. Oleh karena itu pemerintah menggeser hari libur lebaran ke akhir tahun di bulan Desember. Dengan harapan pandemi ini sudah bisa dikendalikan dan masyarakat bisa libur panjang dengan melakukan rekreasi.

Beberapa daerah destinasi wisata favorit bagi turis mancanegara yaitu Bali, Lombok, Yogyakarta, Jakarta, Bandung, Surabaya, Magelang, Bintan, Flores, wakatobi dan Makassar.

Akhir kata semoga virus covid19 ini segera berakhir atau dapat dikendalikan sehingga sektor pariwisata bisa bergairah kembali. Karena sektor pariwisata akan membuat trickle down effect atau efek merembes ke bawah. Teori ini menyatakan bahwa terjadinya kegiatan yang lain akibat dari dilakukannya kegiatan yang lain. Ketika sektor pariwisata ini berkembang maka akan memicu industry lainnya berkembang. Diantaranya perhotelan, transportasi, kuliner, umkm yang bergerak dalam bidang ekonomi kreatif dan pada akhirnya akan meningkatkan perputaran uang di daerah kunjungan turis mancanegara. Ketika hal tersebut terjadi maka akan menghidupkan perekonomian di daerah tersebut secara local dan juga akan memberi dampak secara nasional.

\section{Kesimpulan}

Hasil penelitian menunjukkan bahwa devisa dan turis mancanegara mengalami penurunan yang sangat besar sejak menyebarnya virus Covid19. Temuan penelitian mengimplikasikan bahwa pemerintah harus segera mengambil langkahlangkah yang cepat untuk mengatasi hal ini guna kembali meningkatkan devisa negara.

Untuk penelitian selanjutnya dapat melihat lebih jauh dengan menggunakan analisis kuantitatif dalam melihat hubungan turis dan penerimaan devisa negara.

\section{References}

[1] Aktar, M. A., Sadekin, M. N., \& Saha, S. K. (2014). Relationship between tourist arrival and foreign exchange earnings: The case for Bangladesh. Mediterranean Journal of Social Sciences, 5(16), 162-162.

[2] Databoks.katadata.co.id. (2018, 10 September). Berapa pendapatan devisa dari sektor pariwisata Indonesia. Diakses pada 6 Juni 2020, dari https://databoks.katadata.co.id/datapublish/2 
018/09/10/berapa-pendapatan-devisa-dari-

sektor-pariwisata-indonesia

[3] Economy.okezone.com. (2020, 16 April).

Turis asing anjlok, 50 devisa sektor pariwisata lenyap akibat virus corona. Diakses pada 5 Juni 2020, dari https://economy.okezone.com/read/2020/04/ 16/320/2200241/turis-asing-anjlok-50devisa-sektor-pariwisata-lenyap-akibatvirus-corona

[4] Febriyenti, M., Aimon, H., \& Azhar, Z. (2013). Faktor-faktor yang mempengaruhi cadangan devisa dan net ekspor di Indonesia. Jurnal Kajian Ekonomi, 2(03).

[5] Gandhi, D. V. 2006. Pengelolaan cadangan devisa di Bank Indonesia. Jakarta: PPSK BI.

[6] Sayoga, P., \& Tan, S. (2017). Analisis cadangan devisa Indonesia dan faktor-faktor yang mempengaruhinya. Jurnal Paradigma Ekonomika, 12(1), 25-30. 